$$
\sigma^{\prime}{ }_{\text {Th\% }}=0.046 \times 7.96 / 100=0.0039(\%)
$$

$\mathrm{ThL}_{\alpha 11}$ 㧊よび $\mathrm{SrK}_{\alpha}$ の 回折角におけるバックグラウンドの值 に伴なら計数誤差は実際には， $N=3 \times 128000$ カウント測定して えた值に伴なら計数誤差ですなく，N=128000 カウント測定し てえた值に伴なら計数誤差でもなく，これらの中間数を測定して えた值に伴なら計数誤差に等しいようなものであると考光られ る。したがって計数操作より求めた，トリウム定量値 (Th\%) に対する理論的標準偏差 ( $\sigma$ ) は実際にはつぎのよ5な関係にあ りながら $\sigma_{\mathrm{Th} \%}$ に近いものと考学られる。

$\sigma_{\mathrm{Th} \% \leqq \sigma<\sigma^{\prime} \mathrm{Th} \%}$ すなわち $0.0032 \leqq \sigma<0.0039$

（b）．カウント数が最も少なかった場合：（a）の場合と同様 に計算するこをによってつぎのような結果がえられた。

したがって

$$
\sigma_{\mathrm{Th} \%}=0.0037 \quad \sigma^{\prime} \mathrm{Th} \%=0.0045
$$

$$
0.0037 \leqq \sigma<0.0045
$$

以上の計算結果（5）乱よび（6）から金属ウラン中のトリウ 厶定量の各実験に対する理椧的計数誤差はそのカウント数からつ ぎのようなるのと思われる。

$$
0.003<\sigma<0.004
$$

表 3 の金属ウラン中のトリウムの定量結果の 1 回測定のときの 標準偏差 $\sigma_{1}=0.003$ と, 上飞求めた計数䛊差（7）を比較する ことによって，本法によってトリウムを定量した場合の定量誤差
は初めの仮定ど括りに計数操作に関する誤差（計数誤差）に基い ていることがわかった。したがってX線強度の測定精度をよくす ることによって定量誤差を少なくできることが推定され，表 3 の $\sigma_{1}$ 执よび $\sigma_{2}$ の間の $\sigma_{2}<\sigma_{1}$ なる関係はこのことを示しているよ うに思われる。また ThL $\mathrm{Th}_{\alpha 1}$ の強度が弱いのでこのものの測定䛊 差は $\mathrm{SrK}_{\alpha}$ の測定䛊差にくらべ極めて大きく，定量誤差の主要部 を占めている ( $\varepsilon_{\mathrm{Th}}$ が $\varepsilon_{\mathrm{Sr}}$ に比し大)。このような場合，測定所 要時間も考慮し, 計数值 $N$ を適当に大きくして $\mathrm{ThL}_{\alpha 1}$ の強度 $\left(I_{\mathrm{Th}}\right)$ を $\mathrm{SrK}_{a}$ の強度 $\left(I_{\mathrm{Sr}}\right)$ の精度と同程度に精度よく测定す るならば，本実験のように全測定をくり返すよりも少ない時間で よい精度が期待でさるものと思われる※4。なお $\sigma_{\mathrm{Th} \%}$ と $\sigma^{\prime}{ }_{\mathrm{Th}} \%$ の差が余り大きくないことから $4 \cdot 2 \cdot 2$ でも述べたよ に持ける，バックグラウンドの測定を省き，他の 2 点の測定值か ら， ThL $\alpha_{\alpha 1}$ ，および $\mathrm{SrK}_{\alpha}$ の回折角に拈けるバックグラウンドを 求めても差支卡なよ5に思われる。

（ 本報は昭和 35 年 4 月，日化第 13 年会で講演）

終りに臨み種々扣世話になった名古屋大学教授野田稻吉先生に 厚く御礼申し上げます。

$※ 4$ この場合 $\mathrm{ThL}_{\alpha 1}$ と $\mathrm{SrK}_{\alpha}$ の強度関係はゴニオメーターの 走査速度を早くして $2 \% \mathrm{~min}$ ぐらい）因 4 のように記録さ せれば $\left(2 \theta=28 \sim 25^{\circ}\right.$ の所要時間 1.5 分), 経験的に簡単 にNの值は決められる。

\title{
螢光 $\mathrm{X}$ 線分析法による不銹鋼中の $\mathrm{Cr}$ の定量
}

一Ni 括よび Mo 含有量に対する補正係数を使用する方法—

（昭 和 35 年 9 月 9 日受 理）

䄻 木 弘 三*

螢光 X線分析法による特殊鋼主成分元素の非破壊定量分析において，しばしば大きな誤差を生じて問題となった不銹鋼 中の $\mathrm{Cr}$ の定量に， $\mathrm{Ni}$ および Mo の含有量に応じて補正を行なった $\mathrm{CrK} \alpha$ 線強度から $\mathrm{Cr}$ 含有量を求める新しい方法 を提出した。

この方法では $\mathrm{Ni}$ および Mo を含まない $13 \mathrm{Cr}$ 鋼についての直線的 $\mathrm{Cr}$ 検量線を基準にして $\mathrm{Ni}$ 扰よび Mo\%につ いてそれぞれの補正係数を実験的に求め，これを用いて補正した $\mathrm{Cr}$ 線強度をすべて $\mathrm{Ni}$ や $\mathrm{Mo}$ を含まない $13 \mathrm{Cr}$ 鋼検 量線上飞あるものとして Cr\%を求めたが，各種組成の多数の不銹鋼試料について極めて满足な結果で，Crを定量する ことが出来た。さらに Ni および $\mathrm{Mo} \%$ がともに $\mathrm{K}_{\alpha}$ 線をとれば簡単な直線関係から，それぞれ定量されることを利用 し， Cr， Ni， Mo 線の測定強度から三者を算出する実用的なノモグラフを作成した。

このよ5な方法によって，螢光 X線工業分析に重要な不銹鋼中の $\mathrm{Cr}$ の定量は始めて赛用的な正確さと簡易さをるって 実施されることになった。

\section{1 緒 言}

著者らは，さきに螢光X線分析法の特徵を生かした特殊鋼主成 分元素の非破壞定量分析法について報告した ${ }^{1,2)}$ 。この5ち $\mathrm{Ni}<$ $0.2 \%$ てr $\mathrm{Cr} 11 \sim 16 \%$ の $13 \mathrm{Cr}$ 鋼, $\mathrm{Ni} 7 \sim 14 \%$ で $\mathrm{Cr} 16 \sim 22$ \%の 18-8 鋼, およびそれらに Mo 0〜2.5\%を含んだ鋼種を 通常包括する不銹鋼中の $\mathrm{Cr}$ の定量に括いては $\mathrm{Cr} \%$ と $\mathrm{CrK}_{\infty}$ 線強度（cps）の間にたた 1 本の単純な直線関係が得られず，上

* 横浜国立大学工学部：横浜市南区大岡町.

1) 桃木他, 鉄と鋼 9,988 (1960).

2) 平野他, 学振提出資料, 19 委 5908 , 分光 28 .
の鋼種全体に適合する統一的な検量線を与えるこえが困難であっ た。すなわち表 1 に示した計 9 個の不銹鋼について測定した結果 は図 1 のごとく，これにただ 1 本の検量線を与兄得るものとすれ ば図 1 の実線で示した值線となり，その標準偏差は $0.62 \% \mathrm{Cr}$ にも及ぶことがわかった。この標準偏差の值は先に報告した特殊 鋼中他の主成分元素に物ける值に比較してきわめて大きく，一般 に $0.1 \sim 0.2 \%$ 程度の標準偏差が容易に得られる金属の非破壊營 光X線工業分析においては $0.1 \sim 0.2 \%$ の標準偏差を有する検量 線を作成することを目標にすべきで，標準偏差 $0.62 \%$ の検量線 を直ちに採用するのは困難であった。

このような結果は共存元素による吸収励起効果の総合によると 


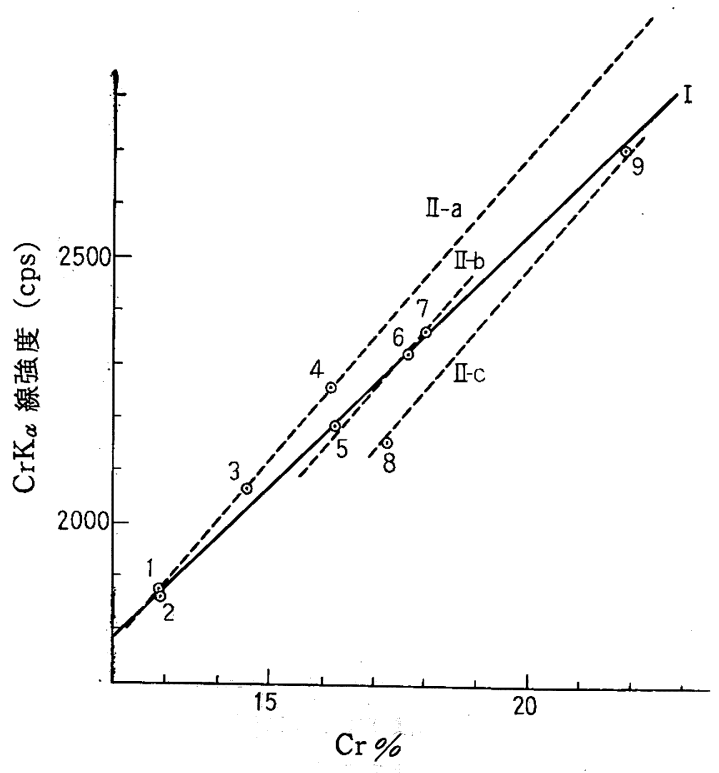

図 1 不銹鋼中 $\mathrm{Cr} \%$ と $\mathrm{CrK}_{\alpha}$ 線強度の関係 (1〜9 は装 1 の陚料番号以対応している)

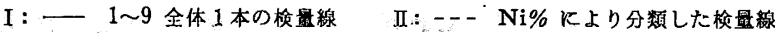
II -a, $1 \sim 4: \mathrm{Ni}<0.2 \%$ II -b, $5 \sim 7: \mathrm{Ni} 7 \sim 10 \%$ II -c, $8 \sim 9: \mathrm{Ni} 13 \sim 14 \%$

表 1 図 1 の測定に使用した不銹鋼試料の組成

\begin{tabular}{cccc} 
娬料番号 & $\mathrm{Cr} \%$ & $\mathrm{Ni} \%$ & Mo \% \\
\hline 1 & 12.86 & 0.15 & - \\
2 & 12.86 & 0.16 & - \\
3 & 14.56 & 0.21 & - \\
4 & 16.13 & 0.18 & - \\
5 & 16.26 & 7.11 & - \\
6 & 17.65 & 10.23 & - \\
7 & 18.00 & 9.33 & - \\
8 & 17.22 & 13.05 & 2.36 \\
9 & 21.84 & 14.22 & -
\end{tabular}

考えられ，先進の米国に却いてもしばしば問題となって吸収 パラメーター法 ${ }^{3)}$ ，その他 ${ }^{4,5)}$ の数学的解法を生んだが，これらは 一般にかなり面倒な計算や近似のくり返しを必要とする上に，偏 差も非実用的に大きく, 分析目的というよりはむしろ $\mathrm{Cr}$ 線強度 に $\mathrm{Ni}, \mathrm{Mo}, \mathrm{Fe}$ 等が影響すべきことを半定量的に示したにすぎ ないよ5に思われた。そして遂に試料をいったん溶解して溶液状 態で測定する方法6) まで提案されたが，実用的非破壊分析に扣い ては類似組成と比較するほか最近も NBS 標準試料を使用した鋼 種別検量線の例 ${ }^{7)}$ が見られ，これも図1によく似たばらつきを有 していて，相当に標準偏差の大きい定量に甘んじて扣るよ5に見 られるのであった。

この問題に対して著者らは，先の報告1,2)に拈いて $\mathrm{CrK}_{\alpha}$ 分析 線強度に対する $\mathrm{Ni}$ の影響を直観的に指摘し，図1亿点線で示し たように戋料の扣よその $\mathrm{Ni} \%$ に応じて分類した 3 本のほぼ平 行な検量湶を用意することによって，日常試料の分析に十分な成 果を収ぬたが，引続いて Ni \% の影響を定量的な補正係数の形 で測定し得ることを知り，実験をくり返して不銹鋼中の Cr の定 量に新しい実用的方法を見出すことが出来た。

本報の方法は一見 Mitchel1 ${ }^{8)}$ が粉末試料に行なった補正係数

3) H. J. Beattie, R. M. Brissey, Anal. Chem. 26, 980 (1954).

4) G. E. Noakes, ASTM. Sp. Tech. Publ. 157, 57 (1954).

5) H.D. Burnham, et al, Anal. Chem. 29, 1827 (1957).

6) W.W.Houk, L. Silverman, ibid., 31, 1069 (1959).

7) J.S. Buhler, NorelcoPeptr. VI, 3 (1959).
法と類似しているが，この考えが適用出来るとは全く思われなか った非破壊の金属試料㹸しても応用の道を開いたものであり， しかも直接化学分析されないため取扱いに考虑を要する Fe を大 晅に無視し $\mathrm{Ni}$ 扣よび Mo の補正係数のみに 注目して少なくと も実用的にはよいことを示した点で全く新しい性格を有する。そ の上吸収パラメーター法などにくらへて遙かに簡単容易で実用し らる正確さをも有している。さらに実用的見地から作成したノモ グラフの使用は極めて有効で，このような方法によって始めて不 銹鋼中の Cr の定量分析は日常的にも実施し得るものとなった。

なお，本法の結果から Cr 分析線に対する $\mathrm{Ni}$ および Mo の 影響機構についても考察を行なったが, 従来の概念は吸収パラメ ーター法などについて述べたとおり半定量的または定性的にすぎ ないのでこれから本法の推論を批判したり影響機構に結論を下 したりすることは出来なかった。むしろ本法は逆にこのような点 について今まで得られなかった定量的な手掛りを始めて与える意 味でも新しい道を開いて扣り，今後各種多数の系について補正係 数のデータを積重ねた上で総合的判断をすることによって，次第 に各種の機構が明らかになり, 螢光X線分析強度の具体的意味す 明らかになるものと思われた。従って本報告の考察も結論的なこ とを示さず，実験事実の可能な二つの場合を述へるに止めた。

\section{2 装置, 試料および測定条件}

装置は理学電機製で, 試料と测定条件の選定は前報1,2) と同様 であった。 $\mathrm{CrK}_{\alpha}$ 線強度の測定にはゴニオメーター $(2 \theta)=69^{\circ} 20^{\prime}$ ， 管球 $40 \mathrm{kV}, 5 \mathrm{~mA}$ でパルパイ (pulse height analyzer) のゲイ ン (gain) 7 , 底電位 (base line) 3.0 , 測定幅 (window) $20 \mathrm{~V}$, 定数 (fixed count) $128 \times 10^{3}$ の条件を用いた。日間変動に対し ては標準試料 1 個について毎時管球電流を調節する方法 ${ }^{9}$ を採用 した。

\section{$3 \mathrm{CrK}_{\alpha}$ 分析線強度と $\mathrm{Ni} \%$ との関係}

上に述べたように著者らは不銹鋼中 $\mathrm{Cr}$ 定量の検量線として困 1 に点線で示した 3 本のほぼ平行な直線を先に採用した。そして これを上より順に $\mathrm{Ni}<0.2 \% ， \mathrm{Ni} 7 \sim 10 \% ， \mathrm{Ni} 13 \sim 14 \%$ に対 応させたが，これは図 1 の点 4 と点 5 の関係からも明らかなとお り，ほとんど同じ Cr\%に拈いても点 5 は点 4 の必ず下方に来 て明瞭な差が見られ，この差が試料に Ni を含む（点 5) か含ま ない（点 4）かによっていることを值観したからである。この傾 向を他の点についても概観し，Ni\%のほぼ同一の点を結んで 3 本の点線を作成した。

この際 $\mathrm{Ni} \%$ の多いほど下方に来て，しかもこれらをほぼ平 行に結んだことは， Ni \% が Cr 分析線強度に何んらかの吸収効 果を及ぼし Ni\% の多いほど連続的に $\mathrm{Cr}$ 線強度を弱める作用※1 をしていると想像したわけである。この吸収作用※1 が何を意味 するかの考察は後にも述べるように微妙で簡単には結論されない

8) B. J. Mitchell, Anal. Chem. 30, 1894 (1958).

9) 桃木, 分析化学, 印刷中.

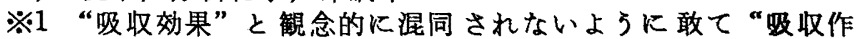
用”なる語を使った。“吸収效果”といえば，なぜ $\mathrm{Ni}$ たは後出の Mo だけに吸収効果があるのかが問題になる。 後にす論ずるよ5に吸収効果には励起効果の総合として外 部にあらわれた結果が“Ni\%のふえるほど $\mathrm{Cr}$ 線強度の 弱く出るような対応を示している”だけで，本質はとるか く，仮に“”の現象を $\mathrm{Ni}$ の吸収作用とよんだのである。 


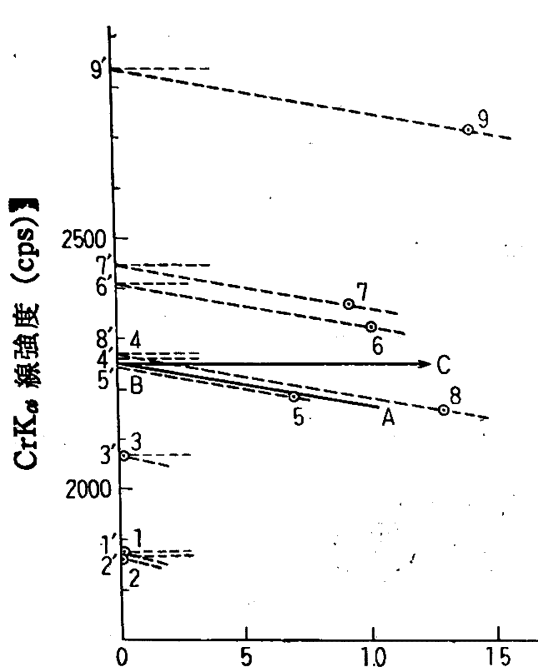

$\mathrm{Ni}(\%)$

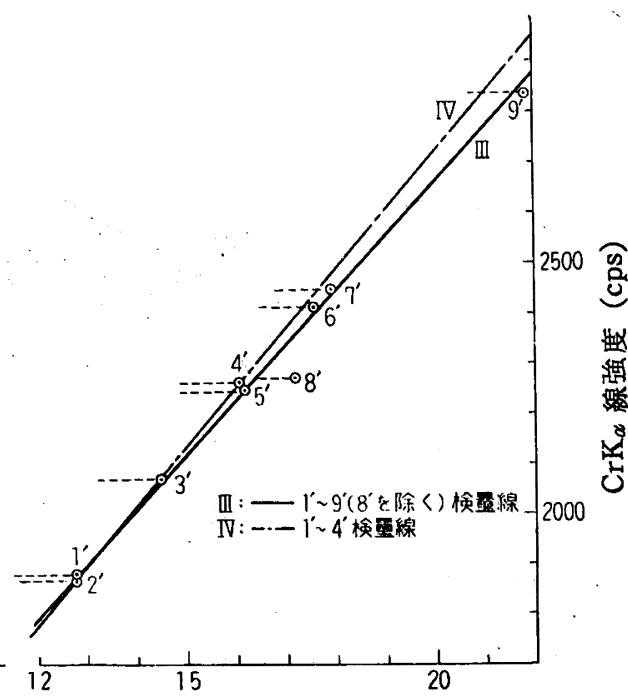

$\mathrm{Cr}(\%)$
(1) $\mathrm{CrK}_{\alpha}$ 線強度と $\mathrm{Ni} \%$ との関係

（2） $\mathrm{Ni}-0 \%$ に外插した $\mathrm{Cr}-\mathrm{K}_{\alpha}$ 線強度 と $\mathrm{Cr} \%$ との関係

因 2 不銹鋼の. $\mathrm{CrK}_{a}$ 線強度に対する $\mathrm{Ni} \%$ の影響

の傾斜としたがう吸収作用を有していること が推察された。

\section{$4 \mathrm{Ni}$ 補正係数の測定}

上に述べた図 2(2) の正検量線は $\mathrm{Ni} \%$ K ついて補正すればかなり正確な $\mathrm{Cr}$ の定量を 行ない得る可能性を示したが，よく見れば， II検量線にには図 1 の I に拈けるばらつきの 傾向がまだ残って括り※3，再び図2（2）に 破線で示した $\mathbb{N}$ 検量線 $(\mathrm{Ni}<0.2 \%)$ と比較 してやはり $\mathrm{Ni}$ の多い $5^{\prime}, 6^{\prime}, 7^{\prime}, 9^{\prime}$ の点は Ni の多いほど下方に来るように思われた。 さらに多数の未知試料に図 2(1) の方法を とるにしても図上で補正するのは雑で面倒で あり， $\mathrm{AB}$ の傾斜が実験的により明確に定め られれば Ni\% に応じた補正項を予め決めら れるわけであるが， $\mathrm{AB}$ の傾斜をすべての $\mathrm{Ni}$ \% そついて一定とした仮定にも疑問があっ て，これが上の正検量線の観察とも関係して

と思われたが，ともかく上の測定結果が果して Ni \% の多くな るほど Cr 線強度を弱くするように作用しているかどうかをさら に定量的に検討することを考え，つぎのようにして Ni\%の吸 収作用をほほ認めることが出来た。

すなわち，図2の（1）に示したように図 1 の測定結果を Ni\% に対して記点した。これらの点の高さ (cps) はもちろん $\mathrm{Cr} \%$ にも関係しているから，図 2 (1) の記点を眺めただけでは cps に Ni\% が密接な関係をもつかどうかはわからないが，もし $\mathrm{Cr}$ \% が一定で Ni\% が変わってゆく等 $\mathrm{Cr}$ 線が図上に引ければ, これによって Ni \% の影響をほぼ定量的に知ることが出来るも のと考えた。

この場合の等 $\mathrm{Cr}$ 線は, 前にあげた点 4 と点 5 がほとんど同じ $\mathrm{Cr} \%(4: \mathrm{Cr}=16.13 \%, 5: \mathrm{Cr}=16.26 \%)$ を有することに注目 し，点 4 のすぐ下と点 5 のすぐ上を通る直線 $\mathrm{AB}$ を引いて代表 させることにした。 $\mathrm{AB}$ は $\mathrm{Cr} 16.2 \%$ なる試料の $\mathrm{CrK} \mathrm{K}_{\alpha}$ 線強度 の変化が $\mathrm{Ni} \%$ の変化飞'対応していることをあらわす等 $\mathrm{Cr}$ 線 で Ni が多くなるほど Cr 線が弱くなる吸収作用を示して沏り， $\mathrm{Ni} 0 \%$ の $\mathrm{cps}$ 軸との交点 $\mathrm{B}$ は $\mathrm{Cr} 16.1 \%, \mathrm{Ni} 0 \%$ の $\mathrm{CrK}_{\alpha}$ 線 強度と考えられた。そして他の点についてもすべて同じ傾斜をむ った等 $\mathrm{Cr}$ 線が引けるるのと見なし※2， $\mathrm{AB}$ に平行線を引いて cps 軸との交点 $1^{\prime} \sim 9^{\prime}$ を求めた。 $1^{\prime} \sim 9^{\prime}$ はそれぞれの $\mathrm{Cr} \%$ を 保ちながら AB の傾斜にしたがって Ni 0\% まで外插したと考 えた場合の $\mathrm{Cr}$ 線強度で， $\mathrm{Ni} \%$ をこのよ5に補正してすべてを Ni 0\% に直したものといらこともできた。

ここで得られた $1^{\prime} \sim 9^{\prime}$ の cpsを図 2（2）のごとくCr\% に対して再び記点したが，8' を除いて直線性は極めて良好で, 図1のI検量線が Ni\%を上のようにかなり雑に補正しただけ で広い範囲にわたって Cr\%のみにしたがう而に補正される可 能性を強くした。 $8^{\prime}$ は Mo $2.4 \%$ を特に含んだ試料で除外して 考えたが，後に示すよ5に Mo\%むまた同様の吸収作用を呈す ることがわかった。そしてこれを除いた吕検量線は図から目測で 1'〜9'の cps を読取ったにもかかわらず標準偏差は約 $0.15 \%$ $\mathrm{Cr}$ と推定されてIの場合より遙かに小さく， Ni\%がほぼ $\mathrm{AB}$
別種の考察を必要とするように思われた。

すなわち，この場合は $\mathrm{MnK}_{\infty}$ 線への $\mathrm{CrK} \beta$ 影響》とは異なり， 本質はともかくある種の吸収効果に基いて括り，Mitchell ${ }^{8)}$ が粉 末で示したと同様実験的には

$$
(\mathrm{cps})_{\mathrm{Cr}}=(a \times \mathrm{Cr} \%) \times\left(1-b_{1} \times \mathrm{Ni} \%\right)
$$

なる形に書くべきすのと思われた。ここに (cps) Cr は Cr 線の 測定強度（cps）であり，( $a \times \mathrm{Cr} \%)$ の項は $\mathrm{Ni} 0 \%$ の $\mathrm{Cr}$ 検量 線上にある点の $\mathrm{cps}$ をあらわす※4。また $b_{1} \times \mathrm{Ni} \%$ は $\mathrm{Ni}$ の影 響を示す項で ${ }^{5}-b_{1}$ ( $b_{1}$ は定数) はこの場合負の作用を示す。 図 2(1) では $\mathrm{Ni}$ 軸に平行に引いた直線 $\mathrm{BC}$ からのA点の”下 り”を単に $b^{\prime} \times \mathrm{Ni} \%\left(b^{\prime}\right.$ は定数) と考えているが，（1）式で はこれが Ni\%のみならず Cr\%にも関係があり $(a \times \mathrm{Cr} \%) \times$ $\left(b_{1} \times \mathrm{Ni} \%\right)$ としているわけである。そして両者の差は $\mathrm{Ni} \%$ の 近いところを見れば大したことはないが，全体としては正とNの 差として Cr\% のないほどそのくいちがいの大きな結果を生じ て怙り，特に 9'のごとく特別 $\mathrm{Cr} \%$ の大きいるのでは亚だけを とってもこの下に位置することを説明出来るものであった。

(1) はまた

$$
(a \times \mathrm{Cr} \%)=(\mathrm{cps})_{\mathrm{cr}} \times\left(1+b_{2} \times \mathrm{Ni} \%\right)
$$

とも考兄らるが，こうして $(\mathrm{cps})_{\mathrm{cr}} /(a \times \mathrm{Cr} \%)$ または（ $a \times$ $\mathrm{Cr} \%) /(\mathrm{cps})_{\mathrm{Cr}}$ なる比をとれば $-b_{1} \times \mathrm{Ni} \%$ または $+b_{2} \times \mathrm{Ni} \%$

※2これは後に述べるように正確ではない。後の議論では $\mathrm{Ni}$ \%の多い注ど等 $\mathrm{Cr}$ 線の傾斜は大きくなるが，ここでは 6〜9 のそれぞれ $\mathrm{Ni} \%$ 異なる点についての等 $\mathrm{Cr}$ 線は図 上に得られないので 5 について（4 を用いて）推定したも のをすバてに適用して大略の見当をつけた。

※3 AB の傾斜を小さくすると $5^{\prime} \sim 9^{\prime}$ は下がるが $1^{\prime} \sim 4^{\prime}$ はほ とんど変わらず，全体として見れば図1の 1９９配置に 近くなる。AB の傾斜を大きくした時は逆に $5^{\prime} \sim 9^{\prime}$ は上 がるが $9^{\prime}$ と同じだけ $5^{\prime} ， 6^{\prime}, 7^{\prime}$ る上がり，図 1 の傾向は いずれにしてる依然残って来る。

※4 一般に多少の定数項打も含み, 本実験のことくバックグラ ウンドを差引かないピーク值のみをとれば定数項は必ず入 って来る。ここでは定数項も含めて $\mathrm{Ni} 0 \%$ の $\mathrm{Cr}$ 㭘量 線上の $\mathrm{cps}$ を $(a \times \mathrm{Cr} \%)$ なる記号であらわした。

※5 ※4 と同样定数項があっても含めた記号である。 
の項が $\mathrm{Cr}$ 線測定強度に対する $\mathrm{Ni}$ の補正係数となり，この補正 係数を用いて測定した $(\mathrm{cps})_{\mathrm{Cr}}$ を補正すれば，Ni 0\% の検量線 のみで Ni％の影響を受けない Cr の定量が行なわれると考兄 られた。

ここで基準となる $\mathrm{Ni} \mathrm{0 \%} \mathrm{の} \mathrm{Cr}$ 検量線には，水溶液等と異な り, Ni 0\% で Cr が広い範囲で次第に変化する任意試料は得ら れなかったので, II-a の $13 \mathrm{Cr}$ 鋼検量線を採用することにし, $\mathrm{Ni}<0.2 \%$ の試料 9 個を用いてこれを作成し直した。この際用い た試料の $\mathrm{Cr} \%$ は 1〜4 亿相当する 13〜16\% にすぎなかった が, 得られた II-a 検量線は 9 の $22 \% \mathrm{Cr}$ までも成立すると仮 定した。 $\mathrm{Ni}$ は平均 $0.17 \%$ で，先に $(a \times \mathrm{Cr} \%)$ であらわした 基準検量線はこの場合の $\mathrm{cps}$ を $(\mathrm{cps})^{0}{ }^{0} \mathrm{Cr}$ として

$$
\mathrm{Cr} \%=0.008447 \times(\mathrm{cps})^{0} \mathrm{Cr}-2.927
$$

となり，標準偏差は $0.086 \% \mathrm{Cr}$ で前報1)とほぼ一致していた。

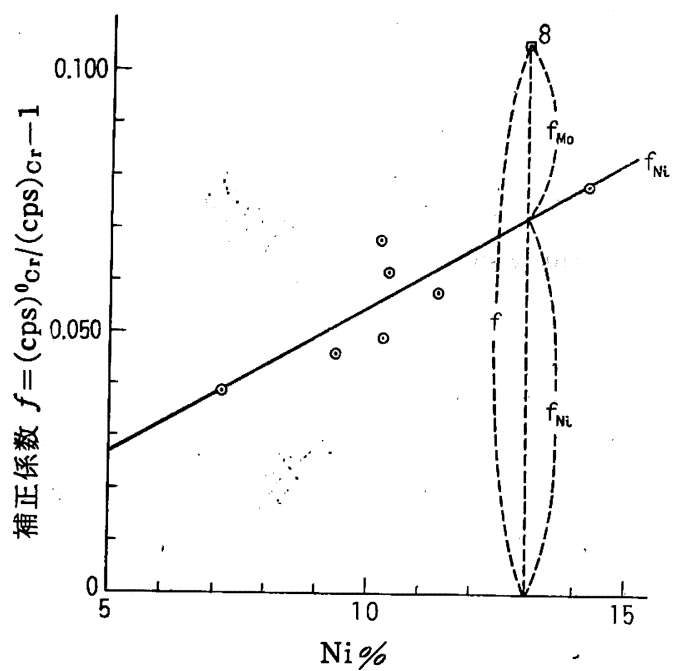

図 $3 \mathrm{Ni}$ 補正係数の測定拈よび全補正係数 $f$ と $f_{\mathrm{Ni}}, f_{\mathrm{Mo}}$ との関係

$\mathrm{Ni}$ 補正係数の測定には Ni 7〜14\% で Mo を含まない 18-8 鋼 7 個をとり，この测定強度 (cps) cr と，化学分析による $\mathrm{Cr}$ $\%$ の值を（3）式に代入して得た $(\mathrm{cps})^{0} \mathrm{Cr}_{\mathrm{r}}$ とから $(\mathrm{cps})^{0} \mathrm{Cr} /$ (cps) $\mathrm{Cr}_{r}-1=f$ を求め, これを $\mathrm{Ni} \%$ につてて記点した図 3 か ら $\mathrm{Ni}$ 補正係数 $f_{\mathrm{N} 1}$ を決定した。 $f_{\mathrm{Ni}}$ は (2) 式の $\left(b_{\dot{2}} \times \mathrm{Ni} \%\right)$ の項に相当し

$$
f_{\mathrm{Ni}}=0.001 \times(5.6 \times \mathrm{Ni} \%-1.3)
$$

となった。（4）式で Ni\% は小数 1 位まで，また $f_{\mathrm{Ni}}$ は $10^{-3}$ の桁までとれば十分であった。こうして $\left(1+f_{\mathrm{Ni}}\right)$ を測定された (cps) $\mathrm{Cr}_{\mathrm{r}}$ にかけて (cps) ${ }^{0} \mathrm{Or}$ を求め，(3) 式に代入して $\mathrm{Cr} \% を$ 決定することになる。一般の 7〜14\% Ni の不銹鋼では測定強度 (cps) $\mathrm{Cr}_{\mathrm{r}}$ の 4〜9\%に相当する補正が必要になった。な括 $f_{\mathrm{N} 1}$ のばらつきは $\mathrm{Cr} \%$ に直して標準偏差 $0.15 \% \mathrm{Cr}$ と測定された が，これが本法に打ける Cr 定量の標準偏差にほぼ相当するもの と思われた。

\section{Mo 補正係数の測定}

図 3 Kは先に除外した Mo 入り不銹鋼 8 の点を同時に記点し ておいたが, Mo 入り試料について測定した $(\mathrm{cps})^{0} \mathrm{C}_{\mathrm{r}} /(\mathrm{cps})_{\mathrm{C}_{\mathrm{r}}}$ -1=fはいずれもこのように $f_{\mathrm{Ni}}$ 直線のかなり上方に配置して いた。これらの試料は同時に Ni 7〜14\%をも含むものであっ て, 図に示したように相当した $f_{\mathrm{N} 1}$ の上方の 部分が $\mathrm{Ni}$ の場合

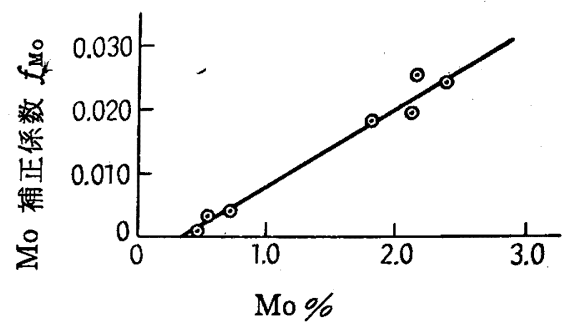

図 4 Mo 補正係数の測定

と同様な Mo 補正係数 $f_{M o}$ と考えられた。すなわち

$$
f=f_{\mathrm{N} 1}+f_{\mathrm{Mo}}
$$

として $f-f_{\mathrm{N} i}=f_{\mathrm{Mo}}$ から測定した $f_{\mathrm{Mo}}$ を Mo 入り試料 7 個につ いてMo\%に対し記点して図4 の関係を得た。図4 K対しては

$$
f_{\text {Mo }}=0.001 \times(12.3 \times \text { Mo\%-4.6) }
$$

が得られて， $f_{\text {Mo }}$ はやはり Mo\% の增加するほど Cr 線強度の 弱くなる吸収作用をあらわすことが明らかであった。

こうして得られた $f_{M o}$ は $f_{\mathrm{Ni}}$ とともに測定強度 (cps) $\mathrm{c}_{\mathrm{r}}$ の 補正に

$$
(\mathrm{cps})^{0} \mathrm{Cr}=(\mathrm{cps})_{\mathrm{Cr}} \times\left(1+f_{\mathrm{Ni}}+f_{\mathrm{MO}}\right)
$$

なる簡単な形を与える。これが実は，上には説明を行なわなかっ たが，（1）式を捨てて（2）式を採用した理由であり，また図 2 (1) の方法を補正係数法に考方直した一因をるなしていた。 後者の点については図 1 の 8,9 の 2 点を比較すればわかるとお り 8 点が 9 点より $1.2 \% \mathrm{Ni}$ が少ないにもかかわらず， II-a K ほとんど平行な II-c が引けたのは実は Mo の影響を考えなかっ た誤りであって, 図 3 を(cps) ${ }^{0} \mathrm{Cr}-(\mathrm{cps}) \mathrm{cr}_{\mathrm{r}}$ の形であらわすと Mo\% の影響が図 3 のごとく，いちじるしくはあらわれないとこ ろから補正係数法を推察した点にもあったのである。

\section{$6 \mathrm{Ni}$ および Mo 補正係数法による定量結果}

上に述べた補正係数法を $\mathrm{Ni}, \mathrm{Mo}$ を $\mathrm{Cr}$ 以外の主合金元素と した不銹鋼に適用し，表 2 の結果を得た。ここでは化学分析で得 た Ni\%和よび Mo\%をそれぞれ（4）および（6）式に代入 して $f_{\mathrm{Ni}}, f_{\mathrm{Mo}}$ を決定し，（7）式を用いて (cps) ${ }^{0} \mathrm{Cr}$ を求め, （3）式によって Cr\%を算出した。表 2 は多数試料の分析結果 の一部で，不銹鋼中の $\mathrm{Cr}$ 定量法として本法のすぐれていること

\begin{tabular}{|c|c|c|c|c|c|}
\hline \multicolumn{3}{|c|}{ 不銹 鎆 試 料 } & \multicolumn{3}{|c|}{$\mathrm{Cr} \%$} \\
\hline 番号 & $\mathrm{Ni} \%$ & Mo \% & 化学分析値 & 本 法 & 差 \\
\hline 101 & 9.07 & - & 18.43 & 18.27 & -0.16 \\
\hline 102 & 10.00 & - & 18.49 & 18.63 & +0.14 \\
\hline 103 & 11.25 & 0.06 & 18.31 & 18.33 & +0.02 \\
\hline 104 & 8.05 & 0.56 & 18.71 & 18.77 & +0.06 \\
\hline 105 & 8.30 & 0.34 & 18.46 & 18.43 & -0.03 \\
\hline 106 & 8.49 & 0.51 & 17.79 & 17.81 & +0.02 \\
\hline 107 & 10.27 & 0.23 & 18.14 & 18.29 & +0.15 \\
\hline 108 & 11.06 & 2.14 & 17.63 & 17.57 & -0.06 \\
\hline 109 & 10.47 & 2.16 & 17.80 & 17.63 & -0.17 \\
\hline 110 & 12.65 & 2.23 & 16.57 & 16.52 & -0.05 \\
\hline 111 & 15.01 & 2.52 & 17.44 & 17.53 & +0.09 \\
\hline 112 & 0.14 & 0.87 & 11.57 & 11.30 & -0.27 \\
\hline 113 & 0.34 & 0.39 & 12.96 & 12.86 & -0.10 \\
\hline 114 & 0.16 & 0.49 & 16.41 & 16.53 & +0.12 \\
\hline \multirow[t]{2}{*}{115} & 0.17 & 0.48 & 16.88 & 17.00 & +0.12 \\
\hline & & & & 敏 $(\mathrm{Cr} \%)$ & 0.12 \\
\hline
\end{tabular}
を明らかにしている。表 2 のちら 試料番号 112 115 の 4 個は 通常の不銹鋼より Si が多く Ni の少ない鋼種で，一部では耐熱

表 2 化学分析值から算出した Ni およびMoの補正係数 を使用して不銹鋼中の $\mathrm{Cr}$ を定量しした結果 
鋼ともいわれるものであるが，Cr\% の少ないほど（一）に，多 いところでは（十）に出る傾向が見られ，ベースの相違によって 基準検量線の傾斜にやや差があるように思われた。しかし，これ らを含めても表 2 のデータの標準偏差は $0.13 \% \mathrm{Cr}$ にすぎず実 用には十分なるのであった。

\section{7 ノモグラフを利用した補正係数法}

すでに著者が報告した ${ }^{9,10)}$ と拈り，螢光 $\mathrm{X}$ 線分析法においては ノモグラフが極めて有効に使用される。時に本法のごとくよせ算 やかけ算を要するものでは実用的な方向を目指すべき䖝光 X線分 析法として測定強度 (cps) より簡単なノモグラフを用いて目的 \%を算出するのが有利であった。

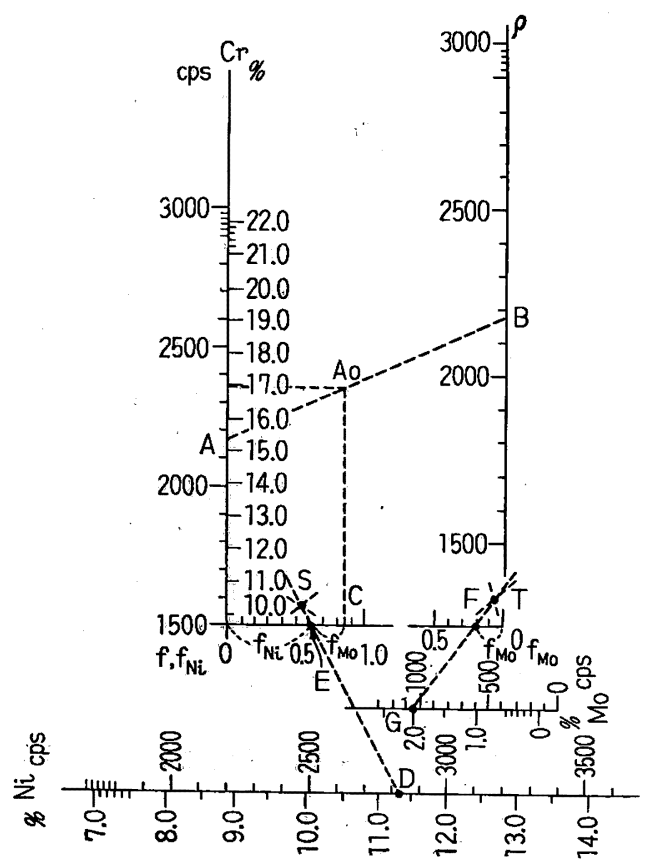

図 $5 \mathrm{Cr}-, \mathrm{Ni}-, \mathrm{Mo}-\mathrm{K}_{\alpha}$ 線の剆定強度より $\mathrm{Cr} \%, \mathrm{Ni} \%$, Mo\%を見出すノモグラフ

補正係数法に対して著者の作成したノモグラフは図 5 に示した ようなものであった。 $\mathrm{Cr}$ 軸, $p$ 軸执よび水平の $f$ 軸からなる上 の部分は（7）式のかけ算を行ならためのもので, 正統的なかけ 算のノモグラフ ${ }^{11)}$ からは異なっているが, 乗数が 1.1 程度で あるからこのような便法がとれた。この考え方は先に述べた日常 分析用ノモグラフ ${ }^{10)}$ と全く同様である。すなわち $\mathrm{Cr}$ 軸には基準 の $13 \mathrm{Cr}$ 鋼検量線を \% c $\mathrm{cps}$ で目盛り, $p$ 軸は水平な $f$ 軸 で 0.2 のところにあるから, $1+f=1+0.2=1.2$ をかけたこと にして Cr 軸の cps 目盛を $20 \%$ 高くした位置に同じ cpsを目 盛る。それには $2500 \times 1.2=3000$ であるから， Cr 軸の 3000 cps のところから水平に引いて同じ高さにある $p$ 軸上の点を求 めてこれを $2500 \mathrm{cps}$ と目盛り，な拈同じ $100 \mathrm{cps}$ 目盛の長さを $p$ 軸では $\mathrm{Cr}$ 軸の 1.2 倍になるよ5に目盛ってゆけばよい。こ うすると $\mathrm{Cr}$ 軸と $p$ 軸で同一の cps を結んだ線上の点がその cps に横軸 $f$ K従った $1+f を f=0 \sim 0.20$ にわたってかけ算を した結果の cps をあらわす。四の $\mathrm{AB}$ は後に示す表 3 中試料番 号 307 の使用例で, (cps) $\mathrm{Cr}_{\mathrm{r}}=2171 \mathrm{cps}$ であったから, Cr 軸上

10)桃木, 分析化学, 印刷中.

11）平田, 化学の領域 14, 421 (1960).
の $2171 \mathrm{cps}$ の点Aとp軸上の $2171 \mathrm{cps}$ の点Bをまず結んだ。 ついでこの場合の $f=0.084$ を $f$ 軸上の $\mathrm{C}$ 点にとり, Cから垂 直に引いて $\mathrm{AB}$ との交点 $\mathrm{A}_{0}$ を求めればよい。 $A_{0}$ 点の $\mathrm{cps}$ は 結局 (7) 式のかけ算を行なって得られた (cps) ${ }^{0} \mathrm{Cr}$ であり, 水平に $\mathrm{Cr}$ 軸尼して \% 目盛を読めば求める $\mathrm{Cr} \%$ となる。 上の例では $(\mathrm{cps})^{0} \mathrm{Cr}_{\mathrm{r}}=2355 \mathrm{cps}, \mathrm{Cr}=16.95 \%$ （化学分析值 17.00\%).が得られた。

下の部分は補正係数 $f$ の算出に $\mathrm{Ni}$ 括よび Mo の $\mathrm{K}_{\alpha}$ 分析線 強度から求めた Ni \%, Mo\%を用いるためにある。不銹鋼中の $\mathrm{Ni}$ および Moは溃光X線分析法により容易に定量されることが わかっており 1,12$)$, 化学分析法を併用しなくても螢光 X 線分析法 だけで補正係数を行なうことが出来た。

$\mathrm{Ni}$ 検量線の湘定条件は $2 \theta=48^{\circ} 38^{\prime}$, パルハイのゲイン 5 , 底 電位 $4.0 \mathrm{~V}$, 測定幅 $20 \mathrm{~V}$, 管球 $40 \mathrm{kV} 5 \mathrm{~mA}$, 定数 $128 \times 10^{3}$ で, Mo の場合は $2 \theta=20^{\circ} 15^{\prime}$ ，パルハイのゲイン 3 , 底電位 5.0 $\mathrm{V}$, 测定幅 $20 \mathrm{~V}$, 管球 $40 \mathrm{kV} 5 \mathrm{~mA}$, 定数 $32 \times 10^{3}$ の条件を採 用し， $\mathrm{Cr}, \mathrm{Ni}, \mathrm{Mo}$ とも同一管球電圧電流で測定するよ 5 にし た。得られた検量線は

$$
\begin{aligned}
& \text { Ni } \%=0.003871 \times(\mathrm{cps})_{\mathrm{Ni}}+0.392 \\
& \text { Mo } \%=0.002252 \times(\mathrm{cps})_{\mathrm{Mo}_{\mathrm{O}}}-0.347
\end{aligned}
$$

であった。

この検量線を水平に図のように引き， $f_{\mathrm{N} 1}$ は前述の $f$ 軸と共通 に, また $f_{M \circ}$ は右側に $f, f_{\mathrm{Ni}}$ と同じ目盛間隔で逆方向に目盛っ た。 $\mathrm{Ni}$ 軸上に任意の $\mathrm{Ni} \%$ の点Dをとり，これに刘応した $f_{\mathrm{N} 1}$ の点 $\mathrm{E}$ を(4) 式から求めて $f$ 軸上にしるす。 $\mathrm{DE}$ を結び, $\mathrm{Ni} \%$ の異なった他の一つの点についても同様に引いて, その交点とし てS点を求めた。このよ5に Ni 軸上の任意の点とそれに対応す る $f_{\mathrm{Ni}}$ を通る直線がいずれも点 Sを通ることは $(4)$ の関係があ る上に $f$ 軸と $\mathrm{Ni}$ 軸が平行であるから当然であり，Mo につい てる全く同様にしてT点が決定された。こうすると（cps）的 を DK, (cps) MoをGKとり, DS, GT のごとく結んで交点 $\mathrm{E}$, $\mathrm{F}$ を求めれば $\mathrm{E} の ~ f$ 座標は $f_{\mathrm{Ni}}$ を, $\mathrm{F}$ は $f_{\mathrm{Mo}}$ を示すことにな る。 $f_{\mathrm{N} 1}+f_{\mathrm{M} 。}$ の上せ算はノモグラフ的にも出来るが，図がごた ごたするので $f_{M o}$ のところに物差をあて目測で $\mathrm{E}$ 点の先に $f_{\mathrm{Mo}}$ だけつぎ足して $f_{\mathrm{Ni}}+f_{\mathrm{Mo}}=f$ の 点を求めることにした。罒の $\mathrm{D}, \mathrm{G}$ は先にも用いた試料 307 の実測例でむる。

こうしたノモグラフを用いて補正係数法を行なった結果は表 3 のと括りで, 工業分析法として極めて満足出来ることを示してい た。

\begin{tabular}{|c|c|c|c|c|c|}
\hline \multirow{2}{*}{$\begin{array}{l}\text { 試料 } \\
\text { 番号 }\end{array}$} & \multicolumn{3}{|c|}{$\mathrm{Cr} \%$} & 俌 & 考 \\
\hline & $\begin{array}{l}\text { ノモグ } \\
\text { ラフ法 }\end{array}$ & $\begin{array}{l}\text { 化学分 } \\
\text { 析 做 }\end{array}$ & 差 & $\begin{array}{c}\mathrm{Ni} \% \\
\text { 测 定 值 }\end{array}$ & $\begin{array}{l}\text { Mo \% } \\
\text { 測 定 値 }\end{array}$ \\
\hline 301 & 16.70 & 16.73 & -0.03 & $6.81(6.89)$ & $-(-)$ \\
\hline 302 & 18.76 & 18.90 & -0.14 & $9.95(10.02)$ & $-(-)$ \\
\hline 303 & 18.78 & 18.58 & +0.20 & $18.59(8.56)$ & $0.68(0.69)$ \\
\hline 304 & 18.45 & 18.50 & +0.05 & $8.75(8.85)$ & $0.48(0.45)$ \\
\hline 305 & 18.61 & 18.48 & +0.13 & $11.15(11.00)$ & $0.23(0.28)$ \\
\hline 306 & 17.30 & 17.36 & -0.06 & $11.27(11 \cdot 39)$ & $2.16(2.17)$ \\
\hline 307 & 16.95 & 17.00 & -0.05 & $11.80(11.27)$ & $2.01(2.05)$ \\
\hline 308 & 18.14 & 18.30 & -0.16 & $10.05(10.19)$ & $0.24(0.21)$ \\
\hline 309 & 15.81 & 16.10 & -0.29 & $-(0.30)$ & $0.54(0.56)$ \\
\hline 310 & 17.24 & 17.17 & +0.07 & $-(0.20)$ & $0.46(0.43)$ \\
\hline & & 啢差 & 0.14 & & \\
\hline
\end{tabular}

表 3 補正係数法にノモグラフを利用した定量結果

注：備考中 Ni \%, Mo\% はノモグラフ上で同時に決定した值で（）は化学分析 値である。本報は $\mathrm{Cr}$ 定量を主題にしてあるので $\mathrm{Ni}$ ，Mo Kついては参为的 な値である。

12) 桃木, 分析化学, 投稿中. 


\section{8 不銹鋼試料の $\mathrm{CrK}_{\alpha}$ 分析線強度に対する $\mathrm{Ni}$ および Mo の影響機構についての考察}

以上の結果は, 実用的な螢光X線工業分析法として不銹鋼中の Cr を定量する際, Ni \% および Mo\%について補正を行なって 正確な結果を得る方法を示しているが，これから Ni および Mo の影響機構について簡単な結論を得ることは次のよ5に困難であ った。

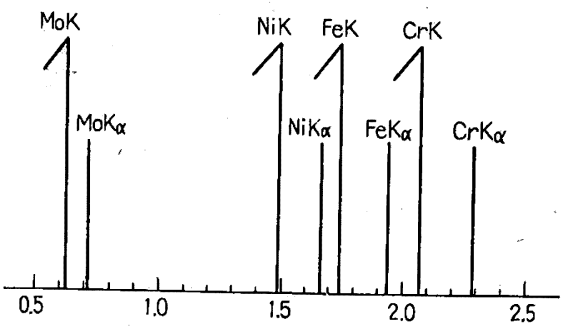

波長 (A)

図 $6 \mathrm{Cr}, \mathrm{Fe}, \mathrm{Ni}, \mathrm{Mo}$ の $\mathrm{K}$ 吸収端波長と $\mathrm{K}_{\alpha}$ 特性 X線との関係

$1 \mathrm{~K}$ 吸收端波長, | $\mathrm{K}_{\alpha}$ 時性X線波長

本法の対象となった試料は $\mathrm{Fe}-\mathrm{Cr}-\mathrm{Ni} の 3$ 元系または $\mathrm{Fe}-\mathrm{Cr}-$ Ni-Mo の 4 元系と考号られ。ここでよく行なわれているよ5 $k^{18,14) ， そ れ そ ゙ れ の ~} \mathrm{~K}$ 吸収端波長と $\mathrm{K}_{\alpha}$ 特性 X線波長の関係を 図6に描いて考察した。図から見ると，問題の Cr に対しては $\mathrm{Fe}$ の大きな励起効果が第一に予想され， Ni の作用は Fe に対 しては強く励起的ではあるが，Cr に対しては単純な吸収が想像 されたが，この吸収は $\mathrm{Cr}$ 線が $\mathrm{Ni}$ 吸収端の左方に近くあるわ けではなく，逆に右にかなり離れて位置するから，特にいちじる

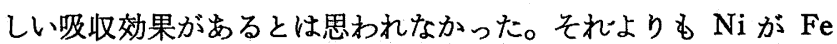
を励起し $\mathrm{Fe}$ がさらに Cr を励起する間接的励起効果む考えられ るはずで，また多少とも $\mathrm{NiK}_{\alpha}$ 線による直接の $\mathrm{CrK}$ 励起もあ り，吸収と励起を差引してどちらが残るにしてす， Ni の作用は それほど大きいとは思われなかった。この点で Beattie らの吸収 パラメーター法3) や Noakes の方法4)ではいずれも Cr 線に 対 する $\mathrm{Ni}$ の励起効果を数学的解析から結果として残しているが, これらを用いた定量結果は本法ほど正確ではなくむしろ図 1 のI 検量線をそのまま用いたものに近く, そのデータから Ni の励起 効果を速断するのは危険であると思われた。

本法に得られた Ni および Mo の吸収作用を統一的に解釈す るため著者は最初 2 これを 1 次励起にあずかるX線部の吸収に帰 した。上に述べた通常の吸収端波長一特性X線波長の議論は 螢光 $\mathrm{X}$ 線部にのみ注意が集って扣り，励起 $\mathrm{X}$ 線部には及んでいない。 しかし螢光 $\mathrm{X}$ 線強度にまず励起 $\mathrm{X}$ 線のエネルギー特にエネルギー 分布が大きな役割を果たすことは，管球電王電流の微細な変化に よっても，炇光線強度がかなり変化することからも当然考えられ た。そして吸收端の左側のかなり狭い範囲に括けるエネルギー分 布が励起に最も関与するとされている ${ }^{15)}$ が，本実験の励起には通

13) I. Adler, J. M. Axelrod, Spectrochim. Acta 7, 91(1955).

14) W. J.Campbell, et al, Anal. Chem. 29, 1009 (1957).

15) E. N. Davis, R. A. Van Nordstrand, Anal. Chem. 26, 973 (1954).
常の如くW管球の連続 X線が用いられ CrK 吸収端付近では連続 $\mathrm{X}$ 線の極大点よりは相当下った右下りの連続的分布が考えられ た。かかる連続分布や，その吸収に対する定量的取扱いは困難で あったが，ごく定性的に概観すれば右下りの分布に対し逆に右上 りの吸収曲線によって吸収がおこるとすれば，吸収端が左側にあ る吸収曲線によるほど Cr 吸収端付近の分布は影響されて弱くな るであろ5。これを本法で Fe-Cr-Ni 3 元系に Ni\% の作用の み考えられた結果と結び付ければ， Ni と Fe のよ5に吸収端の 近いものでは，左側の Ni の影響の方が決定的にあらわれ易いる のと思われた。こうして Ni の吸収端によって Ni\%の多いほ ど強く吸収されて弱くなった励起X線部が，Cr の励起にあずか って拈り， $\mathrm{Fe}$ の $\mathrm{Cr}$ に対する励起をこえて $\mathrm{Cr}$ 線強度に $\mathrm{Ni}$ の 吸収作用としてあらわれたと考えられた。Mo 吸収端は連続X線 の極大点に近く $\mathrm{Ni}$ よりは大きな影響を示すであろうが，これが $f_{\mathrm{Mo}}$ の Mo\%係数が $f_{\mathrm{N} 1}$ より遙かに大きい理由であり，ただ含 有量が少ないので結果的には余り大きな補正値とはなっていない のだと思われた。

これに対して Fe の影響を決定的とする考方方る成り立つよう であった。すなわち， Cr 線強度を決定するのはやはり $\mathrm{Cr}$ に対 する $\mathrm{Fe}$ の励起効果で， $13 \mathrm{Cr}$ 鋼では大さっぱにいって $87 \%$ の $\mathrm{Fe}$ により励起された強度があらわれている。ここに Ni が入れ ば当然 $\mathrm{Fe} \%$ はへり，この分だけ $\mathrm{Cr}$ 線の励起が減少して恰も $\mathrm{Ni}$ の吸収作用が起ったごとく見られると考えたのである。この 考え方は自然で魅力的であるが，入った Ni は同様に Fe を励起 するから考慮せねばならず，これを総合した効果が単純に Ni\% だけに応ずる形で本法のようにあらわせるかどうかは簡単には決 められない。この際最む障害になるのは任意組成の試料がいつで も得られるとは限らない点と， Fe\% が実際には直接化学分析さ れていないので 100\% から分析元素\%を差引いた値が果して実 際の $\mathrm{Fe} \%$ をあらわすかどらか疑問を持たさるを得ない点であ る。特に後者では，鋼中不純物や合金完素の全分析を行うこと自 体が問題で，直接 $\mathrm{Fe} \%$ を定量する分析化学の進歩が望まれる。

以上本法の結果は各種の効果の総合乙して不銹鋼中の $\mathrm{Cr}$ 分析 線強度に対して $\mathrm{Ni}$ および Mo\% が増加するほど Cr 線強度が 减少する結果を，実用し得る分析法としての正確度で与えている むのであって，機構に関しては励起X線説括よび Fe 励起説のい ずれをもごく概念的に与学るが，このいずれをとるべきかに决定 的なものは与えていない。これらを数式的に报った吸収パラメー タ一法その他はすでにその可能性の限界を示して满足しきれない むのとなっている。この方面の議論はすでに観念的な時代を終っ て定量的なことを要望して括り，ここに提出した補正係数法は一 つの試みとして実験的にこれらの影響を論ずる手掛りを与えてい るとも考えられる。そして今後このような補正係数法が各種の系 に応用された上で，それらの補正係数を総合的に判断して始め て, 契際の複雑な系に括ける螢光 $X$ 線強度の具体的意味が第に 明らかになって来るものと思われる。

(昭和 35 年 6 月 4 日, 分析化学討論会において一部発表)

終りに本研究の遂行海援助を賜わった横浜国大河村教授，東 京大学平野教授，試料を御世話下さった特殊製鋼 K. K. 小泉氏， 日本金属工業 K. K. 杉本氏に厚く感謝の意を表する。 